\title{
8 \\ The monologue of liberalism and its imagination of the sacred in minority cultures
}

\author{
Jasdev Singh Rai
}

The particular evolution of Western civilisation has forced upon its artists a responsibility that becomes invalid and obscurantist when transposed upon the cultures of Indic civilisation. The fundamental distinctions between the two civilisations offer different challenges to the artist. But Western hegemony in the arts often clouds critical thinking and encourages the generalisation of inherited western experiences and concepts as universal and transcendent rather than as particular to its own cultural evolution. The arts and the theatre have enjoyed an uninterrupted progress in Indic civilisations for over 3000 years. In that period, subjects such as freedom of expression, boundaries, and sacrilege have been considered in this ancient and pluralistic civilisation, and even articulated in the ancient text of arts and theatre, Natyashastar.

What does the sacred mean in other civilisations, and can it be treated in the same context as the sacred in Western civilisation? In other words, firstly, can civilisations be treated to similar artistic explorations, and can art have intrinsically a uniform role across cultures and civilisations? And secondly, can the Western format of the institution of arts and its temple, the theatre, enjoy the same immunity from the normal etiquettes of engagement in Indic cultures as it does in Western civilisation?

The editors' comment: 'In recent years, issues surrounding the rights of minority cultures to recognition and respect have raised new questions about the contemporariness of the construct of blasphemy and sacrilege. Controversies over the aesthetic representation of the sacred, the exhibition of the sacred as art, and the public display of sacrilegious or blasphemous works have given rise to heated debates and have invited us to reflect on binaries like "artistic and religious sensibilities", "tolerance and philistinism", "the sacred and the profane", "deification and vilification".' This offers an opportunity to open Western discourse on freedom of expression to a different construct of critique in which words such as 'blasphemy' lose their meaning and concepts such as binaries are uncomfortable juxtapositions. There is a paradox in the parody of the passionate 
Western artist struggling against the fabricated demons restricting freedom of expression that he/she assumes exist within ancient civilisations such as Indic. The depth and breadth of freedoms in Indic civilisation have evolved over a much longer period than the experience of freedoms in the West and need to be appreciated in the context of different political and social philosophies that have been prevalent in South Asia.

A principle perspective in the West is a dualist worldview, and inherent in Western civilisation are the concepts of evangelic universalism in almost all fields. A driving force within the imposition of Western philosophical paradigms in the public space is an assumption that at any given time some basic principles or ideas occupying the public space in that particular period are universal without contest: that they are absolutist, from which people deviate at their peril, or the standard toward which others need to strive. Usually only one philosophical paradigm or conceptual framework dominates and determines the public space. For instance, in medieval times, Christian dogma was the universal absolute truth, while post-Enlightenment, secularism and science are the paradigms of truth. It is in this secular paradigm that freedom of expression is often held as an absolute, and from which the purist accuses people of deviating from, or of compromising. ${ }^{l}$ It is within this context that the sacred and the profane exist in Western civilisation and the contest between the artistic and the restrictive is played out in various forms of art. In this binary world, the Church once considered it a triumph to uphold laws against blasphemy, hence restricting freedom of expression. The opposite has now been legitimised in the public space, where the theatre's efforts to push the boundaries of expression even through offence ${ }^{2}$ are seen as a triumph against the traditional restrictions of the Church.

However, to impose this Christian, Western dynamic upon other civilisations and cultures is at best naive, and perhaps constitutes a political statement. There is a fundamental difference between Western and Indic civilisations. The essential philosophy of Indic civilisation destroys generic dualism and absorbs it. It enables multiple philosophical paradigms and conceptual frameworks to occupy the public space at the same time. It also abhors evangelic and assertive universalism and perpetually deconstructs it. Moreover, most Eastern philosophies devalue anthropocentrism. Since dualism is destroyed, the dichotomy of sacred and profane has little relevance in Indic cultures. Therefore, the appreciation of the 'sacred' has to proceed within different perspectives. This chapter argues that the 'sacred' is the creative in Indic civilisations, standing independent of the concept of the profane; and offence is seen as the failure of theatre rather than its triumph over restrictions. Moreover, protection of what is 'sacred' from offence is part of the embedded political philosophy of pluralism. 
The British play, Behzti, which attracted considerable indignation from the Sikhs in Britain and was ultimately forced to close down, was set within the contesting binaries of western philosophy. Its producers had assumed that the Western conceptual and historical evolution of freedom of expression as a universal norm is absolute. They failed to see that the play had transgressed the boundaries of success and entered the arena of failure, as well as the hegemonic politics in their perception of Indic societies as operating within the same binaries.

\section{Principles and pluralism in Indic civilisation}

As a generalisation, the bulk of Eastern philosophy, with some exception such as the Nyaya and Vaisesika schools, ${ }^{3}$ absorbs and devours dualism within most of its strands. The perpetual conflict for hegemony between opposing universalisms becomes redundant in Indic civilisation. The artist is free in Indian civilisation, because the civilisation itself is essentially free from dogma. This is the obvious thing that escapes the Western liberal artist when Indian cultures are 'orientalised' and treated under the rubric of the dualist struggle in terms of which the main body of Western civilisation comprehends reality. Edward Said, who introduced the word 'Orientalism' ${ }^{4}$ in relation to perceptions about the Islamic world, charged the West with failing to understand other cultures and of imposing its own worldview to make sense of others; this misunderstanding was partly romantic and partly demeaning. Such an approach perverts the understanding of alternative cultures, and eventually it leads to the leading Western-educated minds in other cultures internalising the myth created by the West of themselves. Similarly, Western liberalism has generally failed to comprehend the non-dualist world view of the East in practical everyday life. Although many Western intellectuals romanticise it 'intellectually', they rarely understand its practical expression, and often simplify the seeming contradictions in Eastern cultures in Western dualist contests of good-bad, freedom-oppression.

Multiple and sometimes competing complexities fusing into one strand are a feature of the dominant Vedanta school of which the Advaita (meaning non dualist) Vedanta ${ }^{5}$ of Adi Sankara ${ }^{6}$ has inspired most of Hindu thinking. In Vedic thinking, there is not only Brahma the creator, and Shiva the destroyer, but also Vishnu the preserver. One creates, the other destroys, the third preserves. What is destroyed is created again, preserved and destroyed and it goes on. Time and space become irrelevant, as does history. There is harmony among the three rather than conflict. Underlying all this is the still, unmoving Brahaman, ${ }^{7}$ the Eternal in whom everything finally collapses into, who has set this drama, the Lila, an illusion of cycles perceived subjectively by each human mind. Thus, Hindu philosophy obfuscates certainty and undermines fundamentalism anchored in divine revelation. 
In the ordinary tapestry of Indian life, Rama, the god of virtue and charity, can sit with Kali, the god of destruction and sacrifice. The Dharmasashtra, the text of chants of moral duties can be read with the Kama Sutras, the texts of pleasure, in the same temple. Varanasi, the holiest place of worship on the Ganges is not very far from Khajurao, where the temples have bestiality, orgies, homosexuality and heterosexual positions carved on temple walls. The sacred and profane are not seen as in conflict with each other. The tapestry is flattened, all existing in the same domain, the same corner, walking and breathing together without threat from the other or threatening the other.

In the Sikh philosophy, Satguru, the eternal teacher is called by so many attributes and character names that the name loses meaning, becoming 'anaame' 8 (without name) in the Dasaam Granth, the text written during the period of the tenth Sikh Guru, Guru Gobind Singh. The anaame is the benevolent architect of the tranquillity of a quiet beach, and also the alleged demonic destroyer who created the Tsunami ${ }^{9}$ as explained in the Guru Granth Sahib, the textual guide of the Sikhs compiled by the ten Sikh Gurus. ${ }^{10}$ Everything functions within hukam, ${ }^{11}$ the laws, but no one quite understands why things happen, ultimately. ${ }^{12}$ Bad and good are in people's minds. We can venture conjectures on the mechanics, but to understand 'the why' is beyond ordinary language and discourse. No one can know the ultimate truth; therefore no one can claim to have knowledge superior to that of others. ${ }^{13}$

Dialogue and critical discourse is an intrinsic feature of Indic philosophies. Consequently Indian philosophies and cultures are used to disagreements and critical views. But in critique and dialogue, offence is avoided in Indic cultures. For instance, within Sikhi, the trinity of Hinduism (called Trimurti) is not dismissed with a language of condemnation, but it is made irrelevant through subtle critique. ${ }^{14}$ The human can outwit the trinity gods and make a direct connection with the Eternal. The pantheon of Hindu gods is thus made irrelevant. But, in the Sikh scripture, Sri Guru Granth Sahib, the language is never offensive, never commanding, just as it never is in Indic traditions. It initiates a debate within the individual to come up with the desired inference. The one eternal divine reality of Sikhi and the multiple gods of some sections of Hinduism have coexisted in the same territorial, social and political space without either system waging a crusade against the other.

The sacred and profane exist within the same context, in the same dimension, in the same space. They are not demarcated by territory or barriers. Differences exist in people's minds. Therefore, there is no battle for the artist to overcome or external forces to challenge, except people's minds. The success of the artist is to introduce a dialogue within the mind.

But this is where the Natyashastar ${ }^{15}$ places sanctions, as does Kautaliya's Arthashastra. Both prohibit deliberate offence. The reason becomes apparent 
when other aspects of Indian civilisation and the theory of arts are considered. The Natyashastar, written about 2500 years ago, is the text of theatre and arts. The Arthashaster, also written around the same time by Kautaliya, is a text of statecraft and politics, written at least 1500 years before Machiavelli's The Prince.

Most Indic philosophies believe in an eternal drama. Creation is engaged in a drama, the lila (Sanskrit), constructing, deconstructing in perpetual cycles operating concurrently. ${ }^{16}$ Lila is the key concept that enables Indian thinker to escape from universalism and anthropocentrism. There is nothing special about Man. All creation is engaged in this perpetual drama. Some day, humans will become extinct and may rise again. All human ideas are conjectures as no one can penetrate the ultimate reality of the drama. On the other hand, our perceptions are illusions, maya, which are real for us, but in the wider context, part of illusion within the lila.

This enables an enduring plurality and the freedom from hegemonic tendencies. The philosopher is under no compulsion to be an evangelist and spread his inspirations or impose his world view. In Indian tradition, the guru (the guide) waits, and the disciple comes to him. Different gurus have different perspectives. The Nyaya school ${ }^{17}$ is highly analytic, as opposed to the intuitive and even blind belief system of some schools. It uses principles of human reason to deconstruct. The Samkhya school is atheist. ${ }^{18}$ It believes that only what we can see, feel and reason, exists. The Vedanta, the most popular school in Hindu society, believes in the Brahaman, ${ }^{19}$ the creator and the creation as maya, an illusion. Yet, the different schools co-exist in the same town, and in the same Kingdom.

Stated within the acceptable norms of dialogue, nothing is shocking and nothing is really suppressed in Indic civilisation. There is nothing that invites the wrath of the 'Church', as there is no Church. Since there is no concept of the sacred and the profane as distinct entities, everything is sacred. All life, all creativity and all action are sacred. Even rejection of a divine order or a God isn't considered blasphemous, unholy or a sacrilege. In fact, the Samkhya school of Hinduism is atheistic and has coexisted as an alternative philosophy of reality without tension between it and other systems.

Hindu civilisation makes a subtle difference between philosophy and pragmatic everyday life. The differences are manmade. People pray to stone gods, but the philosopher engages in dialectic beyond gods. Beliefs exist in perpetual dialogue with others, with the environment, and with the abstract perception of truth. The individual is free to choose his god and his version of reality, his method of perception and form of sacredness. The individual's engagement is voluntarily. No church or doctrine forces a particular world-view upon the individual. But the culture imposes that he or she accepts and respects the personal space of the other. What one individual considers sacred may seem 
ridiculous to the other. This degree of pluralism survives by each person and community respecting the other for what they are, not what they can be in one's terms.

In this free-for-all world, order is maintained in society through some regulation. Civil regulation is part of society, made sacred, but never so universalist as to warrant crusades to convert other systems. There are at least four versions of the Dharmasutras, ${ }^{20}$ (also named Dharmashastra) the texts of duties, but there have never been conflicts or wars over 'which' Dharmasutra. Whenever domination occurs, it is asserted out of pure desire for power and not in some vague belief in one single absolutist idea of the cosmos and life. There are laws, but they are often made by the hegemonic caste or group. These are not absolute laws. They are enacted and imposed consciously by a section of society for its own benefit, sometimes hideous and unjust laws which function to create privilege. The upper caste claims authority from the ancient sages for these laws and repression of others. But if the Brahmins created the caste for their own power, the sanyasi (ascetics) made the casteless system outside the civil. In traditional India, the towns and villages were often regulated by the Brahmin with rules codified in Manu's laws. ${ }^{21}$ However, the dissenter could legitimately walk out on this and into the almost bohemian and non-materialist life of the sanyasi, with their camps and dwellings in forests. The sanyasi could wander into the towns and villages without fear, but did not stay there to avoid living under civil laws. One version of the Hindu text, Ramayana was written by Valmiki, a sudre (of the low caste), yet Brahmins, not so long ago, cleansed themselves even when the shadow of a sudre prevailed on them.

But one almost universalist concept in Indic civilisation is to limit the scope of gratuitous offence as a weapon of critique, in order to maintain this fiercely pluralistic society. This is the principle that requires the arts and the theatre to avoid offence for the sake of offence, ridicule for the sake of ridicule, or 'profanity' simply to make a point. The sacred is not universal but individual to the person or the community. Each person and each community of believers creates his/her own space outside others. That space is its 'essential' and, therefore sacred. And each creates its own rituals, practices and causes. The rules of dialectic allow critique but not offence. Offensive acts towards or offensive representations of another's sacred is a political statement. It is the equivalent of robbery, impropriety or intended humiliation.

If people were to ridicule the other's choice, make mockery, deliberately offend, and purposely destroy the 'sacred' imagination of another, society would break down into a series of violent retaliations and power struggles. This is the basis of self regulation in Indian civilisation. The distinction between critique and offence is embedded in culture. Since another's god is not imposing any laws upon one's own value system, there is no reason to embark on a campaign 
of humiliating the other's god or the other's beliefs. There is no mileage in parody of the sacred, since the submission to a god or a system is voluntary.

This principle of civility allows the atheist of the school of Samkhya to live as neighbour in the same street as the believer in the elephant god, Ganesh. The person who sacrifices to Kali (goddess of destruction) and the Sikh who rejects this multitude of gods and idol worship and the Muslim who believes in a revealed religion, the Christian who believes in a son of God and the Buddhist who does not ponder about a creator, can coexist. This coexistence would break down if the humanist put up plays offending the others in his or her assumption of superior values, or the Christian stamped on the elephant god as devil worship, the Sikh spat on the idol of Kali, and the Muslim tore down the crucifix of Christ under pretext of freedom of expression. Indian society would simply tear itself apart. Plurality survives on rejection of universality but respect of the other's sacred space.

One of most spectacular living examples of this plurality of beliefs, philosophies and ways of lives is seen at the three-yearly festival of Maha Kumbh Mela, rotating between four cities in India. The Hindu Pantheon, from the nanga sadhus (naked holymen) to the rigidly caste-ist and puritanical Brahmins, come together in a gathering of millions. Nothing creative can shock in the Maha Kumbh Mela. In this grand spectacle of Indian civilisation in performance, there is no absolute ceiling, no divinely ordained universal restrictive laws, and no desecration as understood in Western civilisation. It is a world of believe and let believe.

Perhaps the very concept and terminology of religion is misplaced in Indic cultures. Hinduism has the Dharmasutras, the texts of natural duties, the Shilpasashtra, the texts of science and architecture, the Arthasashtra, the text of politics and statecraft, the Kama Shastrar, the text of pleasure, and the Natyashastra, the text of theatre and arts as well as many other smaller Vedic texts. But they also coalesce. There is the wide-ranging Manu's laws, ${ }^{22}$ which deal with individual moral life, inter-personal interactions, community relations, commerce, politics and in fact most aspects of life. They are part of the so-called sacred cannons of Hinduism. How can these broad fields be classified as religion? They are part of a civilisation that does not differentiate between the religious and the political, between the secular and the spiritual. Indic philosophies tend to work on the premise of a holistic approach and interdependency.

In Sikhi too, the distinction between religion and politics, worship and action, science and spirit, simply do not exist. They are artificial atomistic distinctions created by modernity and when applied to Sikhi, they confuse interpretation and meaning of the Sikh teachings. The word that Indic systems use to describe themselves is 'dharma'. 
The word 'dharma' does not have a direct transliteration in English. Sri Krishna Kant, Vice President of India in 1997, made a clear distinction between dharma and religion. ${ }^{23}$ He described dharma this way:

First and foremost it [dharma] means living in harmony with nature and natural laws. It means to live by moral and ethical principles of the society without surrendering the freedom to question them. The term 'Yuga Dharma' signifies that Dharma itself is continually evolving and not rigid or inflexible. The continuous evolution of Dharma has been through debate, and the triumph of logic, consensus and harmony. Most importantly, Dharma is not linked to any religion or set of beliefs. ${ }^{24}$

The Krishna society describes dharma as 'the inseparable quality that makes a thing what it is. A stone's dharma is to be hard, water's is to be wet, fire's to be hot, sugar's to be sweet'. ${ }^{25}$ The Mahabharat, one of the sacred texts of Hinduism, describes: ('dhaaranaat dharmam ityahuh dharmo dhaarayate prajah,') 'They call it dharma, since it upholds; it is dharma that upholds the people (of the world)'. That which upholds, supports or sustains this universe, without which the universe would disintegrate, is dharma.

The Guru Granth Sahib, the living textual Guru (Guide) of the Sikhs does not use the word mazhab, which translates as 'religion', but the word 'dharam' (a Punjabi word for dharma) as the context of its teachings. There is now a body of work in India which refutes the use of the word 'religion' in reference to Indic systems, and which considers the word to be appropriate to Abrahamic traditions, with a restrictive meaning. The word 'dharma', in my own writings is described as the essence of modern science with the spiritual dimension intrinsic. Thus, it is the elusive truth which science is trying to search and which Indic traditions have been speculating and searching for a long time. Religions, on the other hand, tend to end up in proscriptive truths. (Truth, that is, so-called.)

Therefore, parallels with Western civilisation become irrelevant and irrational. Indic systems never strive to create a single way of thinking or a single 'truth' or system of understanding reality. The civilisation is most at ease when there is pluralism. From this perspective, statements such as 'binaries like artistic and religious sensibilities, tolerance and philistinism, the sacred and the profane, deification and vilification' lose their meaning and context.

\section{The challenge from the universalists}

Indic civilisation has seen an invasion of its systems at least three times, and all from the Abrahamic universalist creeds. First Islam crusaded against India's idols, and then it embarked on an economic and sometimes oppressive program of converting people to its revealed set of universals. The Sikhs, the Marathas and Rajputs (Hindus) rose against the Mughals to stamp out their intolerance. Then Christian zealots and missionaries and neo-scientists came with the Empire, 
openly mocking and ridiculing the gods of the Hindus. Mahatma Gandhi used this offensive and oppressive behaviour of the colonist as one of his campaign logics to drive out the British. The humanists (an atheist version of Abrahamic creeds) gained enough Indian converts and caused mayhem through secular democratic theory (Indian Congress Party) and the communist party. There has been a tension between the 'reformists' and traditional India since independence. But gradually, ancient India is pluralising the liberal universalist. Since all human thought and ideas are conjectures, the very idea of a set of some secular principles being more sacred and universal than the ideas and practices guiding worship of the elephant god is an antithesis of Indic philosophy. More than three thousand years of cultural pluralism has survived by restraining from imposing.

In post-colonial India, modernism with its universalist tendencies, has cast a long shadow in the social, political and arts fields. It has influenced mainly the educated classes. Traditional philosophy is not taught in schools, and people are left to find out about it through religious institutions or general literature. It is only in the last two decades that some critical thinking is emerging on the different conceptual foundations. It is quite common to find that 'educated' Indians think in Western dualist concepts and Western ideas of freedom of expression. No lesser a person than Vice President Krishna Kant commented on this: 'The Western education system forced us to think in Western ways.' ${ }^{26}$ The most likely reason may be discerned from Lord MaCauley's words in February 1835 when he wrote his rationale for a new education system for British India (during the Empire): 'We must at present do our best to form a class who may be interpreters between us and the millions whom we govern; a class of persons, Indian in blood and colour, but English in taste, in opinions, in morals, and in intellect.' ${ }^{27}$ There hasn't been a fundamental reform of the Indian education system since. It is common to find the average Indian brought up on traditional education and knowledge, reacting differently than the educated classes to similar issues. One of them is freedom within the arts. Interestingly, a modernised universalist and united but intolerant form of Hinduism has also emerged from the educated classes which David Ludden ascribes to the influence of modernity. ${ }^{28}$ It is expressed as political Hinduism of the Hindu Mahasabha, an umbrella organisation of Hindu movements which started in the early twentieth century in reaction to British colonialism, and which gave rise to the Bharatya Janata Party (BJP).

\section{Critique and conflicts within Indic discourse}

In Indic civilisation critique is encouraged, a dialogue of disagreement is encouraged and a discourse of rejection of the other's belief through debate (textual, verbal, and visual) is promoted. In fact, the Upanishads are critiques written and discoursed over centuries. However, there is a balance between offence and critique which has been observed in Indian civilisation for centuries. 
When it breaks down, it leads to violence and disruptions. This became evident in the modernised version of Hinduism of the BJP, with its intolerant universalist and united formulation of Hinduism. But ancient India rejects them just as it dislikes the secularist enforcer.

There have been breakdowns and conflicts between different groups in Indian history. They have been conflicts for power. In the Hindu pantheon, even gods fight. The gods of some people win wars over the gods of others. The gods of some are plagiarised. But the culture reverts back to its pluralistic stability and mutual respect. For instance, the Sikh Scripture, the Guru Granth Sahib subtly critiques the Hindu pantheon. The Hindus treat the Granth Sahib with reverence. The Granth Sahib does not offend but critiques, thus respecting, but not agreeing with, the Hindu pantheon.

The arts and particularly theatre is a field in which critique and disagreement has been expressed for centuries. However, this has generally followed guidelines established by the ancient text, the Natyashastar.

\section{Indian arts and theatre, the Natyashastar}

In ancient Indian arts theory, the entirety of existence is itself theatre. The constructed theatre of man is only another drama within it. It therefore evolves, dissolves and plays within the larger theatre of life, ideas and philosophies.

The Natyashastar (or Natyasastra) of Bharata (the writer/s), the oldest text of arts and theatre in India, propounds a sophisticated theory of theatre and of the performing arts. The Natyasastar stands as one of the greatest books from the ancient literature of Indian civilisation and brings the theories of the other shastras into drama. It is a detailed text on the theory, practice and rules of performing arts. Five main principles summarise the Natyashastar. These principles are Artha, Rasa, Abhinaya, Sahmita and Natyadharma. ${ }^{29}$

Artha is the sentiment or the substance that the author wants to convey, that is, the message of the text. In Indian theatre, the text is extremely important, written within the wider philosophy of maya (illusion of reality) as lila (drama). It is not absolutist. It engages human life and the wider drama of existence. The message, the substance, strives to impact through Rasa.

Rasa is the essence. Rasa cultivates the receptive faculties of receivers activating a whole range of responses whose aim is a condition of sahmita (wholeness). Rasa is not a sudden revelation; ${ }^{30}$ it results from a gradual revelation. The performer and the audience become engaged in the whole performance. But bhavas, or states of mind, have to be aroused. The Natyashastar recognises two distinct bhavas. The sthayibhavas, ${ }^{31}$ of which there are nine, are dormant in human nature and aroused by external stimuli, and the vyabhicaribhavas, of which there are $33,,^{32}$ and which are transient and fickle. 
Abhinaya is the variety of props and techniques that give visual form on the stage. This is the function of the actor and the director. ${ }^{33}$

Sahmita is the concept of wholeness. A particular event or a story may be performed, but the story is in the context of the holistic view of life, the intertwining facets of human existence that are essential in Indian philosophy. As Yarrow states from the Natyasastra: 'Art is not diversion, escape, amusement: it is means to wholeness of vision and to the integrated function of perception in more than ordinary modes. ${ }^{34}$ Sahmita also concerns the intrinsic knitting together of artha, the rasa, and abhinaya.

Natyadharma, the rules of drama, determine how, when and what can be put on stage in one form or other. The rules require that the play avoid grim realism, tragic ends, sexually explicit actions, political revolt and offence. ${ }^{35}$ Although theatre in India has made some dramatic departures over time, for instance, plays have put tragic and grim ends (for example, the tragic love operas Heer Ranjha, Sohni Mahiwaal and the Tamil classic Shilappadikaram ${ }^{36}$ ), contained politically subversive messages (in the dramatic political poetry of folk singers called Dhaadis in Sikh uprisings against Mughals, and in Nil Darpan, ${ }^{37}$ an 1860 play that exposed British colonialism's effect on indigo workers and was banned by the British subsequently leading to the Censorship Act of 1876), and have been sexually explicit ( such as the temple dances of Devadasis, which shocked the British), the principle of avoiding offence was retained throughout. However, according to Kautilya's Arthashastra, the guide to State craft, entertainers were permitted to make fun of the customs, castes or families and the practices and love affairs of individuals. ${ }^{38}$ The fine distinction between ridicule, fun and gratuitous offence was maintained. The early Indian cinema stuck close to the five principles of Natyashastar, and modern Indian cinema still avoids offence.

The other aspect of theatre and arts in Indic civilisation is that, unlike Western theatre, the inherited Roman amphitheatre, it generally lacked distinct theatre enclosures with an audience captured in a walled setting. The temple itself was theatre. Theatre travelled to the ordinary person, into the villages, in remote places and in big cities. ${ }^{39}$ It blended.

The performance could last for days, which made the task of the performers extremely difficult as they had to retain the rasa (essence) from day to day, keep the audience engaged, and get the message across. The challenge was to deal with difficult critique without offending, but leaving a deep impression that asked the audience to think for a long time after the performers had left. The play avoided immediate offence, but succeeded in leaving a sentiment and a dialogue within the recipient. 
Thus, the traditional Indian audience is sophisticated, having inherited a pattern of theatre which rejects universality and sustains the general principles of plural life in Indian cultures. Traditionally, Indian theatre has been conscious of the freedom of conscience that allows for a pantheon of beliefs and choices. This gives the artist complete freedom in creativity. Theatre understands that each person and community creates its own sacred space as its identity and its creative activity. The creation of these variable and innumerable forms of creative sacred spaces gives rise to forms of art and expressions of the individual, deliberately transported out of the domain of explanation or reason in many instances. Disparate systems co-exist within a healthy dialectic of critique and doubt. But the art is in learning the boundaries of critique, so the arts never become offensive. This is understood within traditional theatre, which can be provocative without being offensive. The play succeeds if it can engage the audience through rasa, with the artha (the sentiment) that invokes thought rather than anger. It fails if it causes offence and provokes violent response or anger.

\section{Modernity and Indian arts}

In this ancient and highly sophisticated civilisation, modernity has created disruptions. Many Indians educated within Western systems are oblivious of the history and theories of the Natyashastar, and have transformed Indian theatre to a mirage of Western theatre. Indian life has been 'invaded' by western cultural forms. ${ }^{40}$ Theatre is bound by the limits of time and it uses Western theatre theory to be provocative. But the audience of the villages and the traditions are used to a different sophistication in theatre. They do not like the brutal form of theatre of the West. They can appreciate the subtle and entertaining form of Western theatre. But they react adversely when it provokes with offence, because this breaks one of the most sacred principles of Indian plurality, 'respect and be respected', the dialectic of critique without the politics of desecration and hegemony.

It is an irony that the Western liberal cannot teach the traditional Indian freedom of thought as it is intrinsic in Indic civilisation, so he/she reverts to teaching the Indian freedom to offend! But an important question is 'offend what and offend for the sake of what?' If criticism and disagreement is allowed and since no system of belief assumes a position of infallibility, what exactly is offence trying to achieve?

To offend implies a self elevated sense of superiority as the racist in the street does. To offend assumes one knows better than the other. But, according to Indic civilisation all human knowledge is ultimately a myth, a creation of human imagination. The truth remains elusive. The Indic civilisation does not support the belief that there is an objective knowledge out there to be decoded definitively through the empiricism of science. Even science is a human 
construction, a certain way of looking at things, a methodology. In the Indic context, why is the myth of the liberal any superior than that of his predecessor, the Christian or the Muslim? And how are the myths of the Muslim any superior to that of the Christian or the Jew? How are the humanist's ethics any more real than those of the animist or the so called superstition of Ganesh, the elephant god? The humanist calls his creed rational liberalism, the Christian fundamentalist claims his creed to be a divine revelation that cannot be faulted. The extremes of the two exist in tension and compete to claim authentic legitimacy. The use of the weapon of offence in this duel is understandable as neither concedes ground or acknowledge the other to have legitimacy too. When the dialectic breaks down or is restricted, the politics of violence and offence takes over.

The new religion of Western civilisation is a certain construction of human reason, a particular worldview. The liberal is as fanatical as his predecessor, the Christian believer. Just as the Christian wanted to spread the message across the world, and force it down the throats of the rest of the unwitting world, the liberal assumes a similar crusade driven by a belief in the universality of his ideals. When examined in context, the genesis of Western liberal thought from the Enlightenment appears to have failed to address the essential problematic feature of medieval Christian dogma. The sinister fanaticism, the certainty, the universalism that gave rise to the crusades, colonialism, slavery and oppression, has crept through intact into the new liberal creed. Negri's 'Empire' ${ }^{\prime 1}$ is a great expose of the neo-colonialism of liberalism. All that has changed is that faith in the certainty of divine revelation has been replaced by faith in the certainty of human reason. The West stumbled towards freedom from the oppressive restrictions of the Church. But it shows little if any recognition that the 'other' (that is, Indic civilisation) has had freedom for at least three millennia and has no sanction against criticism, no system of inviolable oppressive ethics, no concept of the proscriptive, no problem with freedom of expression and no concept of the sacred as defined in relation to the profane. The distinction between sacred and profane does not exist in Indic theatre. ${ }^{42}$ There isn't comprehension that Indic civilisation does not have a sense of religion in the context of Abrahamic religions. It appears that hegemony seems to empower interpretation and comprehension of the other through one linguistic tool and worldview.

In the Indian context, the profane is the universalist, because it attempts to undermine the basic Indian concept of pluralism. When the sacred is deliberately treated with disrespect, rather than critique, it is seen as the beginning of political universalism, a concept Indian civilisation has successfully contested and defeated time and again through its known 3000 years of civilisation. This was at the heart of the response of the non-Westernised Sikhs in UK to the crude theatre of Behzti. 


\section{Behzti, the contest of civilisations}

We come to the practical: the real drama of Behzti. There were at least three plays in the entire saga: the serious play by Gurpreet Bhatti, the semiotic play by the Birmingham Repertory Theatre (or its director), and the drama out in the street - a clash between two civilisations.

Bhatti's play was simple and straightforward. Written from an orientalist perspective of Sikhi and full of cultural clichés common in liberal fraternity and the Westernised sector of Sikhs, the play tried to deal with the humiliation of women in a religious context. Lacking any deeper understanding of Sikhi, she interposed Christianity as a model of religion upon Sikhi and the Sikh Gurdwara as the institution. The characters involved the president of the Gurdwara and people around him. The play's theme is sexual corruption and financial greed. He is killed by one of his victims. Ms Bhatti admitted that this was pure fiction and without any basis in reality.

The Sikh public is weary of these negative stereotype plays which seem to be the ones that get financial backing and mainstream opportunity for production. However, the Sikhs are used to parody and to jokes about them. Indians joke about Sikhs as the English joke about the Irish. The Sikhs even join in these jokes and joke about themselves. Moreover, fictionalisation of life in theatre is something Indians (and Sikhs) are used to. The Sikh tendency is to ignore these, as they initially did with Bhatti. It is possible that some British-educated Sikhs may have been offended by this type of negative portrayal production and might have written to the theatre or local council. But that is as far as the protest would have gone. The majority of Sikhs, born in India, would simply have brushed off the production. Drama is fiction. There have been controversial and provocative productions by other young Sikh writers in the past, but the Sikhs have simply ignored them or found them amusing. A playwright called Harwant Bains produced a play in which a Sikh cuts his hair on stage and mocks the 'religion'. He tried his best to get publicity by provoking the Sikhs. He went on to claim to have had threatening phone calls, possibilities of demonstrations, etc. The Sikhs simply ignored him. Fiction is fiction. His production died a quiet death.

Moreover, the theme of humiliation of women is not new in Indian theatre, or to the Sikhs. The attempted disrobing of Draupadi the wife of the Pandavs in the epic Mahabharata, the sacred Hindu text about dharma and virtue in war, is a classic narrative in Indian culture. Sikhi, like other Indian philosophies, makes no distinction between the religious and the secular. Inevitably, a narrative of a Sikh man humiliating women would involve the principles, or lack of them, of his dharam (moral duties). Dharam and 'religion' are two different words with different meanings, as described earlier. Indian philosophies call themselves Dharma and not 'religions'. But colonialism insisted on a particular category, 
and hence forced a dichotomy upon Indic cultures. The dichotomy between the religious and the secular is meaningless in an Indian cultural context.

Indian theatre has dealt with the theme of women's humiliation successfully for millennia without offending the audience and yet leaving the message of the writer deeply imprinted in the minds of the audience. The Sikhs expected that subtlety from Bhatti. Many traditional Indians expect writers of Indian origin to know of the traditions in Indian theatre. But disjunctions in cultures and community become apparent in instances such as this which are a theatre of their own. Ironically, neo-Western Indians, ingrained with universalist liberalism, think they are 'educating' their 'provincial' community while the community assumes that such Indians have a critical understanding of their civilisation. These conflicting assumptions were evident in Behzti.

Behzti went a bit far. Not the play, the artha, written by Gurpreet Bhatti, but another play in the background. This was the abhinaya playing silently, whose sole aim was to offend. Abhinaya is the variety of props and techniques that give visual form on the stage. The props used to give form to the play were not fiction nor did they have any relevance to the play. It was a semiotic theatre reminiscent of colonialism, triumphalism and power. This was the director's play; the director wanted to provoke for the sake of provoking, offend for the sake of offending. The director had power, the public's money behind the theatre, and a mere two centuries of fundamentalist Western liberal rhetoric. The director tried to bring an Indic civilisation system into the dual context of Western historical experience and the recently discovered freedom of expression. The director tried to construct the concept of sacred and profane, the triumph of reason over 'religion', an assertion of crude freedom over conjectured proscriptive restrictions. The director tried deflating the icon that is central in the Sikh system and tried to make the essential in Sikhi mundane and irrelevant. The director was on his own little crusade to teach the Sikhs about freedom of theatre and to gain publicity in his attempt. But, for the Sikhs, the play had gone beyond rasa into offence. It was no longer attempting to stage Bhatti's play, but the Director's perversion. The artha, the rasa and the abhinaya had no cohesion, or sahmiti. As far as the Sikhs were concerned, it was no longer theatre but the director's 'safe zone' of intentional humiliation: the offence that was disallowed in Natyashastar. This was no longer theatre nor a creative act, but a political statement. From their perspective, theatre had failed and entered into the politics of neo-colonialist presumption.

The Sikhs, like most Indians, are sophisticated in receiving theatre. Thousands of years of cultural orientation are not lost merely by migrating to another country. Controversy, criticism, subtle deconstruction, bad language, sexual perversions, character assassination, etc, are all acceptable as part of fiction, but 
political humiliation and deliberate offence is not acceptable. It broke the natyadharma and failed to create rasa.

The director brought the Gurdwara and the Guru Granth Sahib's text into the stage where rape and corruption were being staged. From an Indian perspective, this was no longer theatre, but a political statement. At best, it was a misguided political statement imagining a battle between artist's freedom and religious dogma. This has no history or relevance in Indic civilisation. Indian civilisation recognises the artist's total freedom, but also the artist's responsibility towards wider pluralism and the freedom of the individual to his sacred art. It was also clear from the play that the writer had no real knowledge of Sikhi, the institution of Gurdwara, or the benign teachings of Sri Guru Granth Sahib, the living textual guru of Sikhs. The director treated the living created iconology of the Sikhs into his dead world of intellectual discourse, the post enlightenment war between the Western concept of human reason and its assumed irrelevancy of the Abrahamic God in Western public life. At best, it was ignorance of the 'other' because there is no such conflict in Sikhi or Indic civilisation.

Sikhs protested. It is interesting that on the twelfth day, British born non-practicing young Sikhs emerged from the pubs in Birmingham, saw the pain of their community and took matters into hand. They attacked the theatre. Although brought up in Britain, they do not share the British middle class reverence for the Western theatre as a 'sacred' place. The theatre stage has replaced the Church pulpit in the West. At one time in Western history, the pulpit was the safe stage from which war could be waged against ideas of heresy and blasphemy. Now it is the theatre which is the safe stage from which war can be waged against the very concept of ideas being called heresy or blasphemy. But this historic Western conflict between Church and State, between Church dogma and scientific thinking, between Christian proscription and Western liberalism, the perpetual tension of duality, receives little empathy within the civilisation of Indians. Indians have inherited a tapestry of plurality of coexisting imaginations without restriction, and in the minds of Indians, theatre is the drama beyond the confines of the building. The 'magic' 'epic' or 'divine' world co-exists with the everyday (Yarrow). ${ }^{43}$ In the Indian mind, there is nothing sacred about theatre if it breaks from the natyadharma (the rules of engagement in theatre). Once a performer moves away from dharma, he/she forfeits the assumption of sacred 'freedom'.

\section{The Gurdwara as the 'sacred'}

Since everything is maya, an illusion of realities that emerge and then vanish, drama is played in the context of the wider world. According to Sri Guru Granth Sahib: 'This world is an illusion; it dies and it is re-born - it comes and it goes in reincarnation. ${ }^{44}$ The Sikhs believe that every second is a new creation. The 
past dies, its memory only constructed, the present is real for a nanosecond and the future hasn't arrived, it is just conjecture.

The Hindus carry out a special service called Arti. It is worship of the creativity of nature but represented in a plate. Arti is very sacred. The Sikh gurus critiqued this. Arti is the entire world. Everything is in a creative state, dying and reliving. The individual needs to break from the confines of buildings into the broader space that exists around him or her. The sacred space is the wider world, not in a confined theatre or building.

But then, why is the Gurdwara sacred? The Gurdwara is not sacred in the sense of demarcated territory. It is the sovereign territory of Guru Granth Sahib, a text to other people, but which is treated as a human person when it is read. Derrida's philosophy of the differ/ance may help to explain this phenomenon. The Guru Granth Sahib was written by the Sikh Gurus themselves and is in raags (musical format) and cannot be changed, added to or modified. The text is considered as the spoken word without the lag that Derrida conjectures, without the censor of the human mind, without that corruption that takes place between the hidden and the stated. One of the practices in Gurdwaras is to recite the Guru Granth Sahib without an intervening interpretation. The Gurdwara is the residence of the guru. The Sikhs identify themselves with the Guru Granth Sahib, treating it as a living, speaking and engaging entity. It makes no sense to others, but that is the essence of Indian plurality. It is the creative act of every Sikh treating a text as a living person.

The Sikhs do not see the theatre as a sacred territory where the rules of the wider society can be suspended and offence created. But, brought up with pluralism, they respect the Western institution of the apparent 'free' theatre. However, they do not expect this historic western tension played as freedom to colonise their own cultural space. They do not mock it nor humiliate it. Coexistence requires negotiation of mutual respect, not assuming a right to offend the other's sacred. But when the director of the theatre went beyond the Western cultural sphere and dragged in the created sacred of another to humiliate in the theatre's safe territory, the theatre forfeited that respect and war was declared. Like the colonist who used indigenous co-opted intermediaries to legitimise their rule, the director justified his act by pointing out Bhatti's origins in a Sikh family. The Western theatre commands respect from people like the Sikhs as long as it stays within its own boundaries. Once it crosses into the territory of others then it has to respect the rules of the 'other', otherwise it can only enforce its respect with the aid of the coercive power of the State to suppress the people whose otherwise benign indifference is provoked into protecting their own. The Sikhs stood outside the theatre for twelve days quietly protesting, puzzled by the transgression of the director and the theatre's production manager's refusal to engage in a dialogue. Dialogue is at the heart of Indic 
civilisation. The theatre production manager refused 'dialogue'. The manager set up a monologue a few days prior to the play being shown, and then, like the imperialist, decided that the community had to learn 'freedom of the theatre'. The director's crusade, like a colonist, to 'teach' an ancient civilisation the West's newly acquired concept of freedom was an absurdity in itself. Like the French who pursued culture evangelisation in East India in the seventeenth century, only to be thrown out, like the missionaries who caused havoc with their soul-saving crusades in ancient civilisations, the manager-director of the Birmingham Repertory Theatre was on a mission, little realising the comedy of the producer's own position. The director's freedom is that of the adolescent emerging into puberty, full of bravado, threatening without the wisdom of experience. The Sikh has inherited centuries of freedom with the sophistication of critique and drama without crossing the limits of offence.

It is notable that the Sikh representatives who defended the Sikhs' objections to the play in public statements, ${ }^{45}$ made a clear distinction between the artha and the abhinaya, stating that they had no problems with the substance of the play, but objected to the depiction of the Gurdwara and symbolism of Guru Granth Sahib, both of which are their sacred institutions separate from those of others. ${ }^{46}$ In contrast, almost all articles and comments by leading figures from the arts and media, including the petition by 700 leading luminaries of British arts conflated everything into 'freedom of speech' ${ }^{47}$ and 'refusing debate' ${ }^{48}$ or 'the right to challenge religion'! ${ }^{49}$ Most of the articles and statements attacking Sikhs seemed to lack any rationale or analysis and depend more on histrionics. It is still not clear to Sikhs who this debate was supposed to be with, as the audience was largely white middle class and some British educated Indians who rarely if ever go to Gurdwaras. The community that this debate was supposed to be initiated in was enraged by the disrespect shown to the Guru Granth Sahib and the Gurudwara, the 'Rasa' had broken down.

In context, Behzti brought two civilisations into contact but in unfortunate circumstances. From the perspective of Indic civilisation, the West's much protected and prided freedom of expression extending to freedom to offend ${ }^{50}$ in arts and theatre ${ }^{51}$ is but an old conflict being played between those in power and those without power that started in the Roman amphitheatre with its captured audience in a walled confine. The Romans ridiculed the weak in the bloody games in their amphitheatre. After them, the Church saw its right to be free to offend human reason from the theatre of the pulpit. In the twentieth century, human reason assumes a new born right to offend religious doctrine from the theatre of arts. This has no relevance in Indic civilisation which is based on the principle, 'believe and let believe'. Freedom of conscience and expression is a fundamental aspect of the non-dualist Indic civilisation. It allows critique and dialogue but stops at gratuitous offence to preserve and nurture its essential 
plurality. The wider play in Behzti was the interaction between two different civilisations with different historical evolution of ideas and political dynamics of freedoms, and with different philosophical developments. One which sees the right to offend as its sacred duty, while the other which, in the words of Yarrow, 'needs to be recognised...for the subtlety and power of its grasp of the nature and operation of individual and communal effects as embedded in its performance tradition and in Natyasastra' ${ }^{52}$

\section{Endnotes}

${ }^{1}$ In a letter to the editor of the Guardian newspaper (UK) 23 December 2004, 700 of UK's leading figures from the arts world wrote: 'We must defend freedom of expression', and, 'It is a legitimate function of art to provoke debate and sometimes to express controversial ideas. A genuinely free, pluralist society would celebrate this aspect of our culture'. Shelley King, David Edgar and 698 others: 'We must defend freedom of expression', http://arts.guardian.co.uk/news/story/0,,1378818,00.html

2 Nicholas Hytner, the artistic director of the National Theatre, told the BBC that theatre's role was to provoke powerful feelings: 'The giving of offense, the causing of offense, is part of our business,' he said. Alan Cowell, 'Rape, religion and artistic freedom', International Herald Tribune, 29 December 2004. http://www.iht.com/articles/2004/12/28/features/bhatti.php

3 The Nyaya school of Hinduism is an analytic school which believes in the duality of mind and body. The Vaisesika school is atomistic. S. Radhakrishnan, 1989 (1978), Indian philosophy, vol. 2, New Delhi: Oxford University Press.

4 Edward Said, 1978, Orientalism, New York: Vintage Books.

5 Arvind Sharma (ed.) 2004, Advaita Vedanta: An Introduction, New Delhi: Motilal Benarsidas.

6 Adi Sankara was a Hindu monk who articulated the Advaita Vedanta (end of Vedas writings). In modern times, Swami Vivekananda popularised Adi Sankara's work in the nineteenth century.

7 The word 'God' may obscure its understanding.

8 In Jaap, Sahib, Dasaam Granth (the text of the tenth Sikh Guru).

9 Sri Guru Granth Sahib: (Avar na ko māranvārā.) 'There is no other Destroyer than the Eternal,' p. 391, line 2 .

10 The Sikhs have had ten human Gurus, one after the other from 1469 to 1708 . They compiled their teachings during their lives. This compilation in 1430 pages, mostly written in ragas, is called the Sri Guru Granth Sahib and is revered as a living text, in the form of human by the Sikhs. The first eight pages are the poetry of the first Guru, Guru Nanak, called the Jap, in which the Guru sets out the philosophical context of Sikh teachings. From pages 14 to 1353 are the collection of hymns in 31 ragas. The last pages are the poetry of some main spiritual people from around India whose teachings were consistent with those of the Sikh Gurus.

11 Sri Guru Granth Sahib: (Hukm hukam chalā rāhu.) 'The order orders the paths to follow'. Jap, p. 2.

12 Sri Guru Granth Sahib: (Kiv kar Akha kiv salahi kio varni jana.) 'How can we describe, how can we explain what happens, how can we know?' Jap, p. 4.

13 Sri Guru Granth Sahib: (Nanak, akhan sabh ko akhai ik dui k siana.) 'O Nanak, many speak of the eternal truth to others, each one claims to be wiser than others'.

(Vada sahib, badi nai, kita ja ka hove) 'The great master with the most superlative names, ultimately knows what has and will happen'.

(Nanak, je ko apou janai, agai gaia na sohai.) 'O Nanak, one who claims to know everything, shall not be gifted with knowledge beyond his immediate world'. Jap, p. 5.

14 Sri Guru Granth Sahib: (Eka Mai Jugat Viai tin chele parvan) 'One source conceived the entire existence and authorised the three';

(Ik sansari ik bhandari ik lae deban) 'One the creator, one the sustainer and one the destroyer' (talking of Brahma, Vishnu and Siva);

(Jiv tis bhavai tivai chalavai jiv hovai furman) 'Whatever is desired so will happen, they merely follow the order'; 
(Oh vekhai ona nadir na avai bahuta ehu vidan) 'The eternal watches them, but they cannot see the ultimate Source, that is the greatness of this mystery'. Jap, p. 7.

Therefore, in Jap, Guru Nanak subtly asks the audience: Why go through gods who can do no better than the human?

15 Chandra Bhan Gupta, 1954, The Indian Theatre, Munshiram Manoharlal Publishers: New Delhi, p. 107.

16 Bhagvat Gita

17 Radhakrishnan, op. cit., pp. 29-175.

18 Ibid., p. 248.

19 Ibid., p. 430.

20 The four were, Apastamba, Gautama, Baudhayana and Vasistha, P. Olivelle, (trans.), 1999, Dharmasutras, the Law Codes of Ancient India, Oxford: Oxford University Press, Contents and p. xxv.

21 Manu was the lawgiver of ancient India who codified civil rules of behaviour and claimed divine authority for these. It is considered that Manu became the nom de plume for a series of lawgivers.

However, Manu did not claim universal imposition for these laws, and hence they had no meaning in the world of sanyasis.

22 W. Doniger and B. Smith, 1991, The Laws of Manu, London: Penguin Classics, Penguin Books.

23 'In modern day language, Dharma is equated quite unfairly with religion', Sri Krishna Kant, Vice President of India, 1997, Convocation address, Sri Sathya Sai Institute of Higher Education, p. 3. http://www.sssu.edu.in/pdf/CG_Address1997.pdf

24 Ibid.

25 Teachings of A.C. Bhaktivedanta Swami Prabhupada, website owned by Bhaktivedanta Book Trust, http://www.krishna.com/en/node/492

26 Kant, op. cit.

27 T.B. MaCauley, Minute dated 2 February 1835. Bureau of Education, 1965 (1920), Selections from Educational Records, Part I (1781-1839), H. Sharp (ed.), Delhi: National Archives of India, pp. 107-117, http://www.columbia.edu/itc/mealac/pritchett/00generallinks/macaulay/txt_minute_education_1835.html 28 David Ludden, 2006, Making India Hindu, Oxford: Oxford University Press, p. 21.

29 E.W. Marasinghe, 1989, The Sanskrit Theatre and Stagecraft, Delhi: Sri Satguru Publications (India Book Centre).

30 Ibid., p. 185.

31 Ibid., p. 186.

32 Ibid., p. 186.

33 Ibid., p. 197

34 R. Yarrow, 2001, India Theatre, Theatre of Origin, Theatre of Freedom, Richmond, Surrey UK: .Routledge Curzon, p.118.

35 Chandra Bhan Gupta, op. cit., p.107.

36 'The Ankle Bracelet', ,Yarrow, op. cit., p. 113. Yarrow holds that tragic ends and realism is consistent with Sanskrit theatre.

37 Bhatia Nandi, 1963, Acts of Authority/Acts of Resistance: Theatre and Politics in Colonial and Postcolonial India, Michigan: University of Michigan Press, chapter 2.

38 L.N. Rangarajan, 1992, Kautilya, The Arthashastra, New Delhi: Penguin Classics, Peguin Books.

39 Yarrow, op. cit., p.12.

40 Ibid., p. 27.

41 M. Hardt and A. Negri, 2001, Empire, Harvard: Harvard University Press.

42 Yarrow, op. cit., p.12.

Ibid., p. 13.

43 Ibid., p. 12.

44 Sri Guru Granth Sahib, p. 138.

45 'But Gurdial Singh Atwal, a Labour councilor and representative for the Council of Sikh Gurdwaras, said: 'It has caused a great hurt, and shows a lack of respect. The Sikh community had a small demand: rather than setting it in a gurdwara, set it in a community centre.' T. Branigan, 2004, 'Tale of Rape at 
the temple sparks riot at theatre', The Guardian, 20 December, http://arts.guardian.co.uk/news/story/0,,1377285,00.html

46 'But many Sikh representatives argue that the issues have been misunderstood. Harmander Singh, a spokesman for the advocacy group Sikhs in England, said concerns about the setting of the play had gone unheeded for days before the violent protests. Sikh representatives had suggested that the play would be far less offensive if the setting were changed from a temple to a community center, a proposal the theater rejected.' Cowell, op. cit.

47 Sir Christopher Frayling, chairman of the Arts Council said: 'It sends out a message that there are certain subjects about which they must never speak.' Terry Kirby, 2004, 'Violence and vandalism close theatre', The Independent, 21 December, http://www.independent.co.uk/arts/theatre/news/article25779.ece

48 Petition: 'We must defend freedom of expression'. 'It is a legitimate function of art to provoke debate and sometimes to express controversial ideas. A genuinely free, pluralist society would celebrate this aspect of our culture'. Letters, signed by 700 leading illuminaries in the arts: 'We must defend freedom of expression', The Guardian, 23 December 2004,

http://arts.guardian.co.uk/news/story/0,1378818,00.html

49 Dominic Dromgoole, 2004, 'Theatre's role is to challenge religion', The Guardian, 20 December 2004. http://arts.guardian.co.uk/features/story/0,,1377489,00.html

50 "'Artists" power to move brings with it a duty of intellectual integrity. Within the limits this duty imposes, however, they must be free to offend - and this freedom, too, is sacred.' Editorial, Times, 21 December 2004.

51 Nicholas Hytner, the artistic director of the National Theatre, told the BBC that the theatre's role was to provoke powerful feelings: 'The giving of offense, the causing of offense, is part of our business', he said. Cowell, op. cit.

52 Yarrow, op. cit., p. 21. 